Original Article

\title{
Effect of Octopine on Oxidative Stress Indices and Serum Levels of Lipids and Trace Elements in Mice with Breast Cancer
}

\author{
Abdolrasoul Hakim Elahi \\ (PhD Candidate) Department of \\ Biology, Hamedan Branch, Islamic \\ Azad University, Hamedan, Iran \\ Rasoul Sharifi iD \\ $(\mathrm{PhD})$ Department of Biology, Faculty \\ of Basic Sciences, Ahar Branch, \\ Islamic Azad University, Ahar, Iran \\ Minoo Mahmoodi \\ $(\mathrm{PhD})$ Department of \\ Biology, Hamedan Branch, Islamic \\ Azad University, Hamedan, Iran \\ Seyed Mehrdad Kassaee \\ (PhD) Department of \\ Biology, Hamedan Branch, Islamic \\ Azad University, Hamedan, Iran \\ Corresponding author: Rasoul Sharif \\ Email: rasoulsharifi.sci@gmail.com \\ Tel: +989148050927 \\ Address: Department of Biology, \\ Faculty of Basic Sciences, Ahar \\ Branch, Islamic Azad University, \\ Ahar, Iran \\ Received: 2019/08/27 \\ Revised: 2020/03/7 \\ Accepted: 2020/03/7

\section{(c) (i) (3)}

This work is licensed under a Creative Commons Attribution 4.0 License.

DOI: $10.29252 / \mathrm{mlj} .14 .5 .13$

\begin{abstract}
Background and objectives: The aim of this study was to evaluate the effectiveness of octopine (phytogenic-derivative of arginine) on antioxidant indices, trace elements and lipid profiles of a mouse model of breast cancer.
\end{abstract}

Methods: In this study, $48 \mathrm{Balb} / \mathrm{c}$ mice were divided into six groups: healthy control, cancer control, cancer group receiving $50 \mathrm{mg}$ of octopine, cancer group receiving $100 \mathrm{mg}$ of octopine and cancer group receiving $150 \mathrm{mg}$ of octopine. The octopine treatment was carried out for three weeks. The $4 \mathrm{~T} 1$ cell line was used to induce cancer. Fasting blood samples were taken from mice to evaluate lipid profile, copper and zinc levels. Malondialdehyde, superoxide dismutase and glutathione peroxidase activity in breast tumor tissues was evaluated. Data were analyzed by SPSS 18 software using one-way ANOVA and t-test.

Results: Octopine had no significant effect on superoxide dismutase and glutathione peroxidase activity in the treatment group compared with the control cancer group. However, it significantly increased total antioxidant capacity and decreased malondialdehyde activities. Furthermore, treatment with octopine significantly decreased serum zinc, copper, TG, cholesterol and low-density lipoprotein levels but significantly increased high-density lipoprotein compared with the untreated cancer group.

Conclusion: Octopine administration is effective in reducing some oxidative stress indices and improving trace elements abnormalities and lipid profile in mouse models of breast cancer.

Keywords: Octopine, Lipids, Oxidative stress, Trace elements, Breast neoplasms 


\section{INTRODUCTION}

Breast cancer is one of the most common malignancies and a main cause of death in women (1). Of every nine women, one suffers from life-threatening mammary carcinoma, and more than 130,000 women die of breast cancer every year (2). There is a wellestablished relationship between oxidative stress, carcinogenesis and different types of cancer (3). Due to oxidative stress, active oxygen species in cancer cells is increased and the level of antioxidants is decreased (4). Glutathione peroxidase (GPX), superoxide dismutase (SOD) and malondialdehyde (MDA) are clinically important oxidative stress biomarkers of tissues, blood, urine and other body fluids(5). Generally, oxidative damage is often associated with a decrease in the activity of antioxidant enzymes, which itself is dependent on the level of trace elements (6). In this regard, a significant difference in the level of some rare elements including copper and zinc has been reported in patients with cancer (7). Some studies have used the zinc/copper ratio to estimate prognosis of cancer (8). Several studies have shown that plasma levels of copper can be used as a useful indicator of cancer progression or response to treatment (9). Lipoproteins play an important role in the progression of cancer by delivering lipids to tumors. Patients with various cancers show irregular patterns of lipid profiles. However, these patients often have significantly increased serum triglyceride (TG) and decreased cholesterol, high-density lipoprotein (HDL) and low-density lipoprotein (LDL) levels (10). It has been proposed that dietary supplementation of amino acids, such as argentine can have beneficial effects (11). Larginine is a cationic amino acid with anticancer and anti-inflammatory effects (12). Free radical gas-nitric oxide is a main antioxidant agent produced from L-arginine (13). One of the derivatives of arginine is octopine, a phytogenic compound composed of alanine and arginine (14). It belongs to the opine family and generates from the interaction of pyruvate and arginine under the catalytic activity of octopine dehydrogenase (15). To our knowledge, no study has investigated the clinical and anti-cancer effects of opines. Therefore, we aimed to evaluate the effects of octopine on oxidative stress, trace elements and lipid profiles of a mouse model of breast cancer.

\section{MATERIALS AND METHODS}

\section{Cell culture}

The 4T1 cells were cultured in RPMI 1640 medium (Sigma-Aldrich, USA) with $10 \%$ fetal bovine serum, $100 \mathrm{mg} / \mathrm{ml}$ streptomycin, $2 \mathrm{mM}$ L-glutamine and $4.5 \mathrm{~g} / \mathrm{L}$ glucose. The cell culture medium was renewed every 2-3 days. Cells were passaged with $0.25 \%$ trypsin after reaching confluency of $80-90 \%$. The cultures were maintained at $37{ }^{\circ} \mathrm{C}$ and $5 \% \mathrm{CO}_{2}$.

Tumor induction

Methods: In this study, $48 \mathrm{Balb} / \mathrm{c}$ mice were divided into six groups:the healthy control, the cancer control, the cancer group receiving 50 $\mathrm{mg}$ of octopine(as a solution and purchased from Sigma), the cancer group receiving 100 $\mathrm{mg}$ of octopine and the cancer group receiving $150 \mathrm{mg}$ of octopine. The octopine treatment was carried out for three weeks. The 4T1 cell line was used to induce cancer. Fasting blood samples were taken from mice to evaluate lipid profile, copper and zinc levels. Malondialdehyde, superoxide dismutase and glutathione peroxidase activity in breast tumor tissues was evaluated. Data were analyzed by SPSS 18 software using one-way ANOVA and t-test.First, a cell suspension containing 10 million cells $/ \mathrm{ml}$ was prepared in phosphate buffer saline. Then, one million cells were infused adjacent to the mouse lowest left mammary gland (16). Tumor was generated after two weeks and treatment with octopine was initiated on 14th day and continued for three weeks. After appearance of breast tumor, octopine was administered as a solution (prepared in deionized water), once a day for three weeks. The treatment groups received octopine solution by gastric gavage and the control groups received serum physiology by gavage (17).

On 21st day, blood samples were taken the heart of the mice and breast tumor samples were collected and stored at $-70{ }^{\circ} \mathrm{C}$. After lysate preparation, activity of SOD, GPX and MDA as well as total antioxidant capacity (TAC) were measured.

\section{Tumor volume measurement}

Tumor volume was determined using the following formula: $\mathrm{V}=(\mathrm{L} \times \mathrm{W} \times \mathrm{W}) / 2$, where $\mathrm{V}$ is the tumor volume, $\mathrm{L}$ is the tumor length and $\mathrm{W}$ is the tumor width (18). 
Antioxidant indices measurement

The antioxidant capacity was determined by Ferric Reducing Ability of Plasma (FRAP). In this method, colorless ferric-TPTZ complex (Tripyridyl-S-Triazine) is converted to the purple $\mathrm{Fe}^{+2}-$ TPTZ by antioxidants whose maximum absorption is at $593 \mathrm{~nm}$. Increased concentration of the complex and increased absorbance correlates with antioxidant activity (19).

Assessing superoxide dismutase activity

The activity of superoxide dismutase enzyme was assessed using a commercial kit (Manual/Rx Monza-Ransod-Sd 125, Randox Laboratories Ltd. Co., Antrim, UK) according to a method described by L'Abbé and Fischer (20).

Assessing GPX activity

The GPX enzyme activity was measured using a commercial kit (Gpx Manual/Ransel Kit, Randox Laboratories Ltd. Co., Antrim, UK) based on a method described by Paglia and Valentine (21).

Measurement of MDA

Lipid peroxidation level was measured using the thiobarbituric acid method. As the end product of lipid peroxidation, MDA reacts with aqueous thiobarbituric acid at low $\mathrm{pH}$ and high temperature and produces a red colored complex with a maximum absorbance at 532 nm (22).

Measuring lipid profile and trace elements

Serum zinc and copper levels were measured by atomic absorption using commercial kits and the Shimadzu AA-670 apparatus (Kyoto, Japan) (23). Before testing, all samples were diluted with Triton X-100 (1\%) and measured by flame atomic absorption method. Deionized water was used as standard for drawing the proper curve. After selection of proper curve by the apparatus, all samples were injected to apparatus and absorptions were measured. Finally, serum lipid profile was assessed using Pars Azmoon Co. (Iran) kits.

Data analysis
All data were analyzed using SPSS software version 18 . One-way analysis of variance was used to compare the means within groups and the t-test was used to compare means between groups. All statistical analyses were performed at significance level of $<0.05$.

\section{RESULTS}

As shown in figure $1,150 \mathrm{mg}$ of octopine significantly reduced the tumor volume $(\mathrm{P}=0.00)$.

Results of one-way ANOVA and t-test showed that octopine treatment caused a nonsignificant decrease in blood cholesterol compared to untreated cancer group. However, $1500, \mathrm{mg}$ of octopine significantly decreased TG compared to untreated cancer group $(\mathrm{P}=0.01)$. Treatment with 100 and $150 \mathrm{mg}$ of octopine compared resulted in a significant increase in blood HDL $(\mathrm{P}=0.05$ and $\mathrm{p}=0.00$ respectively) compared to the untreated cancer group, and the highest effect was achieved at a concentration of $150 \mathrm{mg}$ octopine. Moreover, consumption of 100 and $150 \mathrm{mg}$ octopine significantly reduced blood LDL ( $\mathrm{p}=0.05$ and $\mathrm{p}=0.04$ respectively) compared to the untreated cancer group, and the highest effect was observed at concentration of $150 \mathrm{mg}$ octopine. As shown in figure 3, octopine treatment (150 $\mathrm{mg}$ ) significantly reduced blood copper $(\mathrm{P}=0.04)$ and zinc $(\mathrm{P}=0.01)$ levels compared to the untreated cancer group. Also, octopine treatment significantly reduced MDA compared to the untreated cancer group, with the highest effect observed at concentration of $150 \mathrm{mg}$ octopine. A significant increase in blood TAC was observed following octopine treatment with different doses $(\mathrm{P}=0.05,0.04$ and 0.01), while the highest effect was observed at concentration of $150 \mathrm{mg}$ octopine. Furthermore, all doses of octopine caused an insignificant increase in GPX and SOD activity (Figure 3 and Table 1).

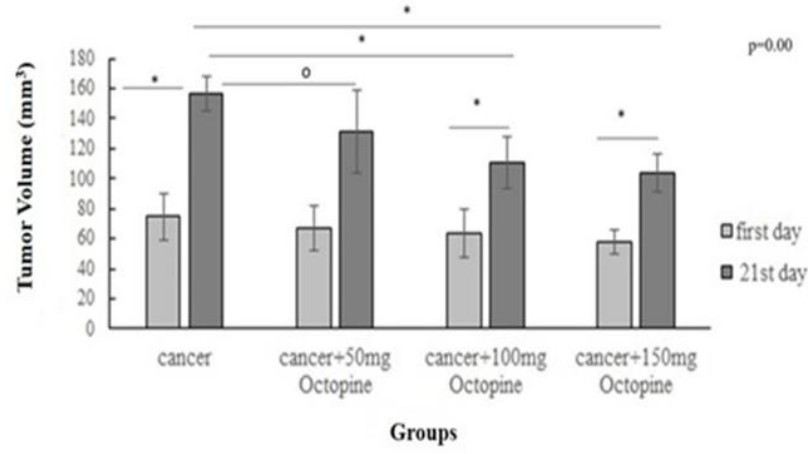

Figure 1. Results of tumor volume measurement in the study groups. *: $P<0.001,{ }^{\circ}: P<0.05$ 


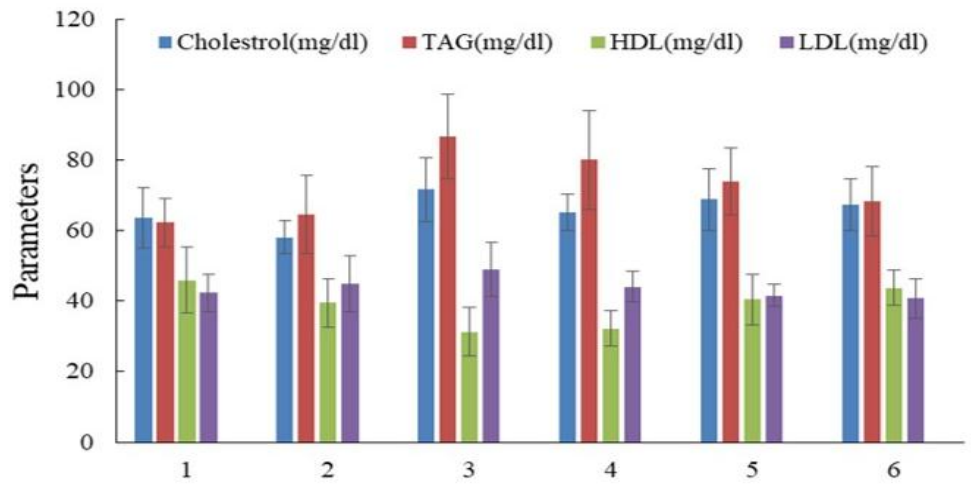

$1=$ Healthy, $2=$ Healthy $+50 \mathrm{mg}$ Octopine, $3=$ Cancer, $4=$ Cancer $+50 \mathrm{mg}$ Octopine, $5=$ Cancer $+100 \mathrm{mg}$ Octopine, $6=$ Cancer $+150 \mathrm{mg}$ Octopine

Figure 2. Mean level of serum cholesterol, TAG, HDL and LDL in different study groups

Table 1. Comparison of SOD activity between the groups

\begin{tabular}{cc} 
Groups & SOD (U/grPro) \\
\hline Healthy control & $175.49 \pm 1170.00$ \\
Healthy + 50mg octopine & $86.89 \pm 1195.00$ \\
Cancer control & $86.12 \pm 1091.66$ \\
Cancer + 50mg octopine & $170.37 \pm 113.33$ \\
Cancer + 100mg octopine & $129.09 \pm 1103.45$ \\
Cancer + 150mg octopine & $159.30 \pm 1131.66$ \\
\hline
\end{tabular}

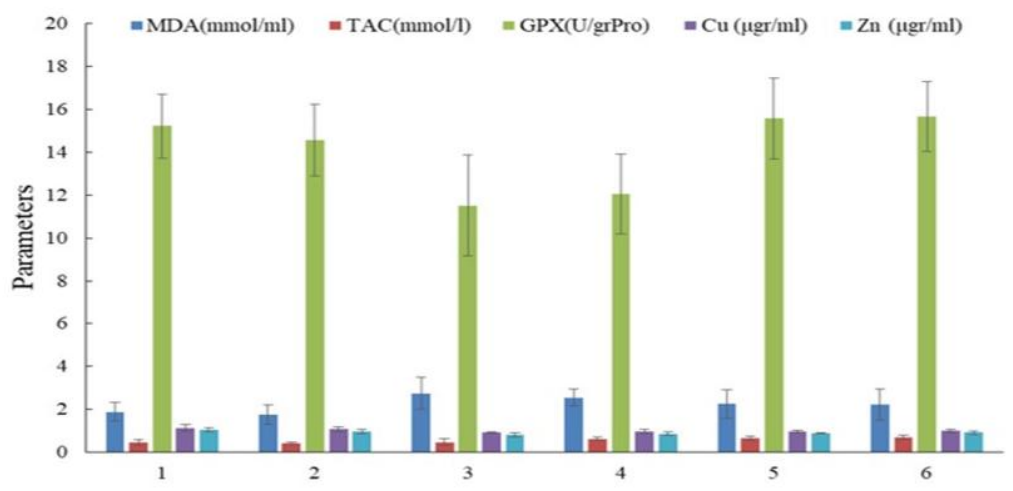

$1=$ Healthy, $2=$ Healthy $+50 \mathrm{mg}$ Octopine, $3=$ Cancer, $4=$ Cancer $+50 \mathrm{mg}$ Octopine, $5=$ Cancer $+100 \mathrm{mg}$ Octopine, $6=$ Cancer $+150 \mathrm{mg}$ Octopine

Figure 3. Comparison of trace elements and oxidative stress indices among the study groups 


\section{DISCUSSION}

Many studies have investigated the changes in the concentrations of different bioelements in body tissue or fluids during cancer. Zinc is an antioxidant and anti-tumor element that naturally inhibits copper, which has a prooxidant property (24). Zinc is involved in the synthesis of metallothionein, an important factor in inhibiting free radicals. Furthermore, it has been demonstrated that zinc chloride reduces DNA breaks in human fibroblasts exposed to ultraviolet radiation (25). These findings infer that there may be an inverse relationship between zinc concentration and cancer risk (26). For example, serum zinc levels were lower in breast cancer patients compared to healthy subjects (27). Skrajnowska et al. reported that copper level in breast cancer tissue is higher than that in normal tissue of rats with breast cancer (28). A study by Koso et al. revealed that high copper concentrations in the serum are likely due to the copper release from necrotic cells (29). On the other hand, cancer cells are under constant oxidative stress and free radicals are recognized as key factors in cancer biology (30). Very few clinical reports are available regarding the anti-cancer activity of octopine. In this study, the use of octopine did not have a significant effect on the antioxidant activity of GPX and SOD. However, octopine treatment significantly decreased and increased the level of MDA and TAC, respectively. This can be due to the presence of arginine in the octopaine structure. Jabecka et al. showed that $2 \mathrm{~g} /$ day L-arginine supplementation for four weeks significantly increases TAC levels in patients with atherosclerosis (31). On the other hand, Lucotti et al. showed that daily consumption of $\mathrm{L}$-arginine ( $8 \mathrm{~g}$ /day) for 21 days results in weight loss and a significant increase in SOD activity (32). In a study, the effect of Larginine on the oxidative stress in diabetes resulted in decreasing the level of MDA in the gastrointestinal tract of rats and the increasing of activity of antioxidant enzymes (33). The serum lipid profile of different tumor types varies widely. It is not clear how increased serum cholesterol is associated with increased mortality (34). Previous studies have reported contradictory results regarding the TG levels in patients with malignancies (35-37). It is clear that serum lipoprotein patterns vary among different tumor types.However, a single tumor type can have different lipoprotein levels based on the disease stage
(38). A study by Sato et al. showed that octopine administration in cholesterol-fed rats significantly reduces LDL and VLDL levels and increases HDL level (39).

\section{CONCLUSION}

Octopine administration is effective in reducing some oxidative stress indices and improving trace elements abnormalities and lipid profile in mouse models of breast cancer.

\section{ACKNOWLEDGEMENTS}

The authors acknowledge the financial support from the Hamedan Islamic Azad University and contribution of Dr. Moharram Sharifi in editing the manuscript.

\section{CONFLICT OF INTEREST}

The authors declare that there is no conflict of interest regarding the publication of this article.

\section{REFERENCES}

1. Siegel LR, Miller D K, Jemal A. Cancer statistics. CA CANCER J CLIN. 2019; 69: 7-34.

2. Tauro M, McGuire J, Lynch CC. New approaches to selectively target cancer-associated matrix metalloproteinase activity. Cancer Metast. Rev. 2014; 33(4): 1043-1057.

3. Gao CM, Takezaki T, Wu JZ, Liu YT, Ding JH, Li SP, et al. Poly-morphisms in thymidylate synthase and methylenetetrahydrofolate reductase genes and the susceptibility to esophageal and stomach cancer with smoking. Asian Pacific Journal of Cancer Prevention. 2004; 5(2): 133-8.

4. Abdel-Salam O, Youness E, Hafez H. The antioxidant status of the plasma in patients with breast cancer undergoing chemotherapy. Open Journal of Molecular and Integrative Physiology. 2011; 1: 29-35. DOI: 10.4236/ojmip.2011.13005.

5. Rao S, Kumari S. Changes in plasma lipid peroxidation and the antioxidant system in women with breast cancer. International Journal of Basic and Applied Sciences. 2012; 1(4): 429-38. DOI: 10.14419/ijbas.v1i4.267.

6. Salganik RI, Solovyova NA, Dikalov SI, Grishaeva ON, Semenova LA, Popovsky AV. Inherited enhancement of hydroxyl radical generation and lipid peroxidation in the $S$ strain rats results in DNA rearrangements, degenerative diseases, and premature aging. Biochem Biophys Res Commun. 1994; 199(2): 726-33.doi: 10.1006/bbrc.1994.1289.

7. Yelinova V, Glazachev Y, Khramtsov V, Kudryashova L, Rykova V, Salganik R. Studies of human and rat blood under oxidative stress: changes in plasma thiol level, antioxidant enzyme activity, protein carbonyl content, and fluidity of erythrocyte membrane. Biochem Biophys Res Commun. 1996; 221(2): 300-3.doi: 10.1006/bbrc.1996.0590.

8. Zhai H, Chen X, Hu Z. Study on the relationship between intake of trace elements and breast cancer mortality with chemometric methodsComputational Biology and Chemistry, 2003; 27(6): 581-86. doi: 10.1016/s14769271(03)00049-5.

9. MacDonald G, Nalvarte I, Smirnova T, Vecchi M, Aceto N, Doelemeyer A, et al. Memo is a copper-dependent redox protein with an essential role in migration and metastasis. Sci Signal. 2014; 7(329): ra56

10. Munir R, Usman H, Hasnain S, Smans K, Kalbacher H, Zaidi N. Atypical plasma lipid profile in cancer patients: Cause or consequence? Biochimie. 2014; 102: 9-18. doi: 10.1016/j.biochi.2014.03.010.

11. Yoon JK, Frankel AE, Feun LG, Ekmekcioglu S, Kim KB. Arginine deprivation therapy for malignant melanoma. Clin Pharmacol. 2013; 5: 11-9. doi:10.2147/ CPAA.S37350.

12. Ekmekcioglu S, Ellerhorst JA, Prieto VG, Johnson MM, Broemeling LD, Grimm EA. Tumor iNOS predicts poor survival for stage III melanoma patients. Int J Cancer. 2006; 119: 861-6. 
13. Kim S-H, Roszik J, Grimm EA, Ekmekcioglu S. Impact of lArginine Metabolism on Immune Response and Anticancer Immunotherapy. Front Oncol. 2018, 8(67): 1-4

14. Hockachka P, Hartline P, Fields J. Octopine as an end product of anaerobic glycolysis in the chambered nautilus. Science. 1997; 195(4273): 72-4.

15. Smits SHJ, Mueller A, Schmitt L, Grieshaber MK. A Structural Basis for Substrate Selectivity and Stereoselectivity in Octopine Dehydrogenase from Pecten maximus. Journal of Molecular Biology. 2008; 381(1): 200-11.

16. Soleimani N, Farhangi B, ashraf Mohabati mobarez, Fatemeh Etyabi. VEGF and MMP-9 Gene Expression Caused by Treatment with Helicobacter Pylori Neutrophilactivating Recombinant Protein in a Breast Cancer Model. JBUMS. 2015, 17(3): 13-19. [Persian]

17. Andrés A, Morales JM, Praga M, Campo C, Lahe17ra $\mathrm{V}$, García-Robles $\mathrm{R}$, et al. L-arginine reverses the antinatriuretic effect of cyclosporin in renal transplant patients. Nephrol Dial Transplant. 1997; 12(7): 1437-40. doi: 10.1093/ndt/12.7.1437.

18. Jones LW, Viglianti BL, Tashjian JA, Kothadia SM, Keir ST, Freedland SJ, et al. Effect of aerobic exercise on tumor physiology in an animal model of human breast cancer. J Appl Physiol. 108(2): 343-8.doi:10.1152/japplphysiol.00424.2009.

19. Benzie IF, Strain J. Ferric reducing/antioxidant power assay: Direct measure of total antioxidant activity of biological fluids and modified version for simultaneous measurement of total antioxidant power and ascorbic acid concentration. Methods in enzymology. 1999; 299: 15-27.

20. L'Abbé MR, Fischer PW. Automated assay of superoxide dismutase in blood. Methods in enzymology. 1990; 186: 2327.doi: 10.1016/0076-6879(90)86113-a.

21. Paglia DE, Valentine WN. Studies on the quantitative and qualitative characterization of erythrocyte glutathione peroxidase. J Lab Clin Med. 1967; 70(1): 158-169.

22. Sabarimuthu D, Pamakanthan SR. Effects of Epicatechin, a Flavonoid on Lipid Peroxidation and Antioxidant in STZInduced Diabetic Rats Liver, Kidney and Heart. Pharmacol Rep. 2005; 57(5): 610-615.

23. Burtis CA, Ashwood ER, Bruns DE. Tietz textbook of clinical chemistry and molecular diagnostics. $5^{\text {th }}$ ed. USA: Elsevier. 2012; 1033-47.

24. Reedy BS, Charles MJ, Rajug NJ, Reddy S, Reddy S, Rama Lakshmi PVB, et al. Trace Elemental Analysis of Cancer Afflicted Intestine by PIXE Technique. Biol Trace Elem Res. 2004; 102(1-3): 265-82. doi: 10.1385/bter:102:1-3:265.

25. O'Connor JM. Trace elements and DNA damage. Biochem Soc Trans. 2001; 29(Pt 2): 354-7.

26. Leccia MT, Richard MJ, Favier A, Beani JC. Zinc protects against ultraviolet A1-induced DNA damage and apoptosis in cultured human fibroblasts. Biol Trace ElemRes. 1999; 69(3): 177-190. DOI: 10.1007/BF02783870.

27. Adzersen KH, Jess P, Freivogel KW, Gerhard I, Bastert G. Raw and cooked vegetables, fruits, selected micronutrients, and breast cancer risk: a case-control study in Germany. Nutr $\begin{array}{llll}\text { Cancer. } & \text { 2003; } & \text { 46(2): } & \text { 131-137. }\end{array}$ 10.1207/S15327914NC4602_05.
28. Skrajnowska D, Bobrowska B, Tokarz A, Kuras M, Rybicki $\mathrm{P}$, Wachowicz M. The Effect of Zinc-and Copper Sulphate Supplementation on Tumor and Hair Concentrations of Trace Elements ( $\mathrm{Zn}, \mathrm{Cu}, \mathrm{Fe}, \mathrm{Ca}, \mathrm{Mg}, \mathrm{P})$ in Rats with DMBA-Induced Breast Cancer. Pol J Environ Stud. 2011; 20(6):1585-1592.

29. Koksoy C, Kavas GO, Akcil E, Kocaturk PA, Kara S, Ozarslan C. Trace elements and superoxide dismutase in benign and malignant breast diseases. Breast

Cancer Res Treat. 1997; 45(1): 1-6.

30. Valko M, Rhodes CJ, Moncol J, Izakovic M, Mazur M. Free radicals, metals and antioxidants in oxidative stress-induced cancer. Chem Biol Interact. 2006; 160(1):1-40

31. Jabecka A, Ast J, Bogdaski P, Drozdowski M, PawlakLemaska K, Cielewicz AR, et al. Oral L-arginine supplementation in patients with mild arterial hypertension and its effect on plasma level of asymmetric dimethylarginine, $L$ citruline, L-arginine and antioxidant status. Eur Rev Med Pharmacol Sci. 2012; 16(12): 1665-74.

32. Lucotti P, Setola E, Monti LD, Galluccio E, Costa S, Sandoli EP, et al. Beneficial effects of a long-term oral Larginine treatment added to a hypocaloric diet and exercise training program in obese, insulin-resistant type 2 diabetic patients. Am J Physiol Endocrinol Metab 2006; 291(5): E90612.

33. Kochar N I, Umathe S. Beneficial effects of L-arginine against diabetes-induced oxidative stress in gastrointestinal tissues in rats. Pharmacological Reports; 2009, 16(4): 665-672.

34. Sharma M, Tuaine J, McLaren B, et al. Chemotherapy agents Alter plasma lipids in breast Cancer patients and show differential effects on lipid metabolism genes in liver cells. PLoS $\begin{array}{llll}\text { One. 2016; } & 11(1): & \text { e0148049. }\end{array}$ 10.1371/journal.pone.0148049.

35. Alexopoulos CG, Blatsios B, Avgerinos A. Serum lipids and lipoprotein disorders in cancer patients. Cancer. 1987; 60(12): 3065-3070.

36. Borrelli R, del Sordo G, De Filippo E, Contaldo F, Parisi V, Beneduce G. High serum HDLcholesterol in pre-and postmenopausal women with breast cancer in southern Italy. Adv Exp Med Biol 1993; 348: 149-153. doi: 10.1007/978-1-46152942-2_17.

37. Knapp ML, Al-Sheibani S, Riches PG. Alterations of serum lipids in breast cancer: Effects of disease activity, treatment and hormonal factors. Clin Chem 1991; 37(12): 2093-2101.

38. Adana A, Llanos P, Makambi KH, Tucker CA. Cholesterol, lipoproteins, and breast cancer risk in African-American women. Ethn Dis. 2012; 22(3): 281-7.

39. Sato M, Nakano T, Takeuchi M, Kanno N, Nagahisa E, Sato Y, Kobatake Y. Effects of octopine on the serum cholesterol level in rats. Bioscience, Biotechnology and Biochemistry. 1996, 60(1): 154-156. DOI: 10.1271/bbb.60.154.

\section{How to Cite:}

This paper should be cited as: A Hakim Elahi R., Sharifi M,. Mahmoodi M,. Kassaee SM. [Effect of Octopine on Oxidative Stress Indices and Serum Levels of Lipids and Trace Elements in Mice with Breast Cancer]. mljgoums. 2020; 14(5):13-18. DOI: 10.29252/mlj.14.5.13 